\title{
GEOLOGIC HAZARDS AND RELATIVE SLOPE STABILITY OF THE INACTIVE PART OF THE SLUMGULLION LANDSLIDE, SOUTHWESTERN COLORADO
}

\author{
By Mario Parise 1 \\ Andrea Moscariello2
}

\section{Open-File Report 97-706}

This report is preliminary and has not been reviewed for conformity with U.S. Geological Survey editorial standards and nomenclature. Any use of trade, product, or firm names is for descriptive purposes only and does not imply endorsement by the U.S. Government.

1National Research Council of Italy

CERIST, via Orabona 4, 70125

Bari, Italy
2Institut F.A. Forel

Universite de Geneve

10 , route de Suisse, $\mathrm{CH}-1290$

Versoix, Suiss 


\section{CONTENTS}

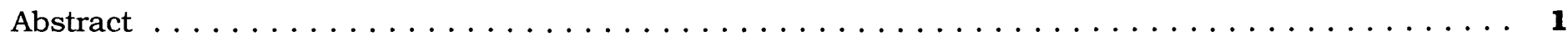

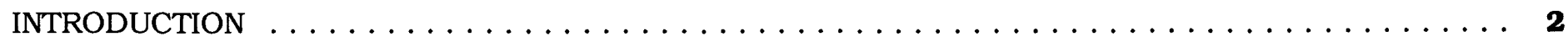

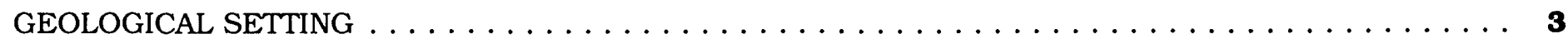

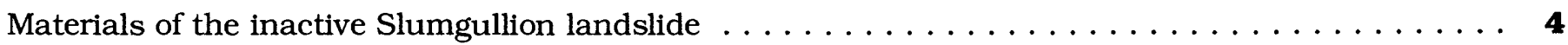

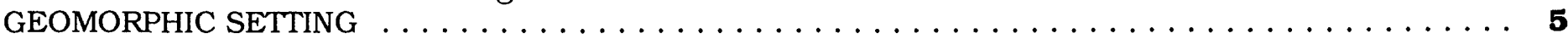

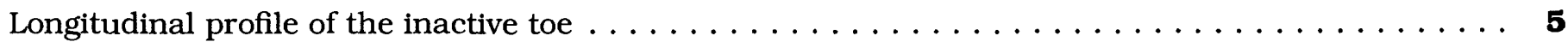

The damming of Lake Fork and the formation of Lake San Cristobal . . . . . . . . . . . . . . . . . 8

THE GEOLOGIC HAZARDS RELATED TO THE INACTIVE SLUMGULLION LANDSLIDE . . . . . . . . 9

Talus accumulation and rock-fall deposits $\ldots \ldots \ldots \ldots \ldots$

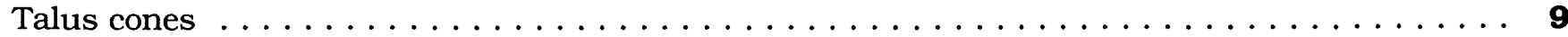

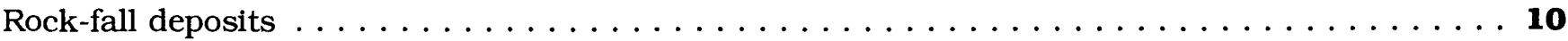

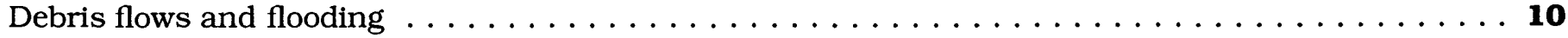

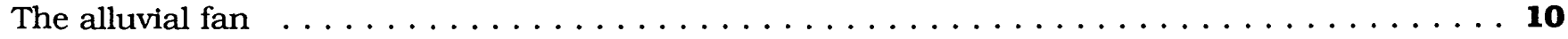

The delta $\ldots \ldots \ldots \ldots \ldots \ldots \ldots \ldots \ldots \ldots \ldots \ldots \ldots \ldots \ldots \ldots \ldots \ldots \ldots \ldots$

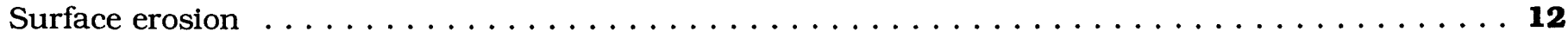

Ground deformation downslope from the active toe $\ldots \ldots \ldots \ldots \ldots \ldots \ldots \ldots \ldots \ldots \ldots$

Secondary slope movements within the inactive Slumgullion landslide deposits $\ldots \ldots \ldots \ldots \ldots 13$

Major collapse of the main scarp and resultant reactivation of the slide deposits $\ldots \ldots \ldots \ldots \ldots 13$

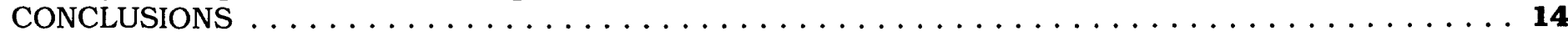

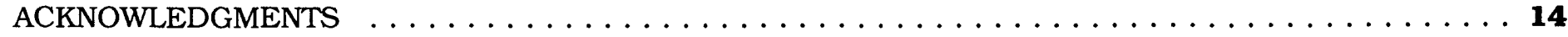

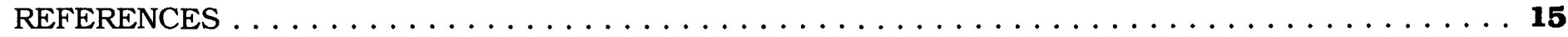

\section{FIGURES}

1. Location map showing the boundaries of both inactive and active parts of the Slumgullion earth flow

2. Geomorphological sketch of the middle-lower portion of the Slumgullion earth flow, from the active to the inactive toe

3. Longitudinal profile of the middle-lower part of the inactive Slumgullion earth flow, starting from the toe of the active earth flow

4. Map of Lake San Cristobal and surrounding areas $\ldots \ldots \ldots \ldots \ldots \ldots \ldots \ldots \ldots \ldots \ldots \ldots \ldots$

5. Geologic map of main scarp of the Slumgullion earth flow, showing the talus cones. $\ldots \ldots \ldots \ldots$

6. Area downhill from the active toe, showing the ground deformation of the inactive landslide deposits

7. Profiles at the main scarp of the inactive Slumgullion landslide

\section{TABLES}

1. Morphometry of the inactive Slumgullion earth flow

2. Dimensions of the landslide dam and of Lake San Cristobal 


\section{Geologic Hazards and Relative Slope Stability of the Inactive Part of the Slumgullion Landslide, Southwestern Colorado}

\section{By Mario Parise and Andrea Moscariello}

\begin{abstract}
The Slumgullion landslide, in southwestern Colorado, is a complex feature consisting of an active landslide currently moving on the upper-middle part of an older, larger, and inactive landslide. The inactive landslide is $6.8 \mathrm{~km}$ long, with an estimated volume of $170 \times 10^{6} \mathrm{~m}^{3}$. The active part is $3.9 \mathrm{~km}$ long, with an estimated volume of $20 \times 10^{6} \mathrm{~m}^{3}$. Dendrochronological data provide a minimum age of 300 years for the younger part, and between 700 and 900 years for the inactive landslide, whose occurrence caused damming of the Lake Fork of the Gunnison River and the formation of Lake San Cristobal. The landslide formed as a result of collapse of hydrothermally altered volcanic rock in the rim of the Lake City Caldera, on the south end of Mesa Seco.
\end{abstract}

This report deals with analysis of the geologic hazards related to the inactive portion of the Slumgullion landslide. After an introduction to the geological and geomorphological setting of the region of the San Juan Mountains where the Slumgullion landslide is located, we describe the main geologic hazards.

The landslide deposits are fine sand, silt, and clay derived from hydrothermally altered volcanic rocks. Locally, large assemblages of boulders are present; in plan view they have an elongated lenticular shape with the long axis parallel to the movement direction of the earth flow. Overall, these materials are elongated in the direction of sliding and have a strong lateral variability.

The longitudinal profile of the inactive landslide, downhill from the toe of the active earth flow, can be divided into four separate zones: 1) a pond-rich region characterized by abundance of water flowing down from the toe of the active landslide; 2) a main bulge, which represents an old internal toe in the inactive earth flow; 3) an area characterized by steps, which correspond to breaks in slope of the underlying topography; 4) and, eventually, the inactive toe, with a uniform $6^{\circ}$ slope.

Other than the possibility of a repeat of a major collapse of a significant part of the main scarp, the principal concerns in terms of hazards are rock-fall and talus accumulation processes at the head scarp, debris-flow and flooding processes in Slumgullion Creek, areas of surficial erosion, deformation of the inactive earth-flow deposit downhill from the active toe, and secondary slope movements within the main body of the earth flow.

The base of the head scarp of the Slumgullion landslide is mantled with a belt of detrital material consisting of talus cones and rock-fall deposits. The talus cones are built by discontinuous accumulation of debris falling from the near-vertical to overhanging rock wall of the main scarp. Rock-fall deposits form irregular hummocks made of clast-supported angular blocks and coarse boulders.

At the mouth of Slumgullion Creek, on the south flank of the slide, a $0.49 \mathrm{~km}^{2}$ alluvial fan is present. The fan consists of several debris-flow and flood deposits comprised of a clast- to matrix-supported assemblage of cobbles, pebbles, and granules with a mud-rich sandy matrix. Due to the presence of several resort facilities close to Slumgullion Creek and within the boundaries of the depositional area of debris-flow materials, the alluvial fan at the mouth of the creek poses one of the most significant hazards related to the Slumgullion earth flow.

Areas of intense surface erosion, generally corresponding to zones of sparse vegetation, are scattered over the inactive earth flow. Rills and gullies develop in these areas, and surface erosion contributes sediment to Lake San Cristobal and the Lake Fork of the Gunnison River.

Loading exerted by currently moving material at the distal end of the active Slumgullion landslide causes ground deformation downslope from the active toe. Total measured downward deformations are in the range from 20 to $80 \mathrm{~mm}$ near the active toe, and the amount of deformation decreases with distance from the toe. State Highway 149 is only $250 \mathrm{~m}$ downhill from the actively deforming area and is in possible jeopardy from a continuation of the current movement pattern of the active toe. 


\section{INTRODUCTION}

The Slumgullion landslide, in the San Juan Mountains of southwestern Colorado (fig. 1), is one of the most famous slope movements in North America. It has attracted the attention of numerous investigators since the beginning of this century (Cross, 1909; Howe, 1909). This landslide is also mentioned in papers dealing with geology and slope movements in the San Juan Mountains (Endlich. 1876; Atwood and Mather, 1932; Burbank, 1947). Recently, the Slumgullion landslide has been the object of detailed studies (Crandell and Varnes, 1960; 1961), and further research was begun by the U.S. Geological Survey in 1990 with the assistance of scientists provided by a cooperative agreement with the Italian National Research Council. The main results of these last studies have been recently published (Varnes and Savage, 1996).

Data defining the kinematics of the movement at Slumgullion site showed that most of the movement of the active part of the Slumgullion earth flow takes place along shear surfaces that bound the landslide on its sides (Guzzi and Parise, 1992; Baum and Fleming, 1996; Savage and Fleming, 1996; Fleming and others, 1996); therefore, it would be most accu- rate to refer to it as earth slide or simply as a landslide. However, since it has long been described as an earth flow and sometimes used as a typical example for this category of slope movements, the term earth flow has become and still remains traditionally popular for the Slumgullion landslide. In this paper, we use interchangeably both the terms earth flow and landslide in referring to the Slumgullion slope movement.

The Slumgullion earth flow is $6.8 \mathrm{~km}$ long (table 1), with an estimated volume of $170 \times 10^{6} \mathrm{~m}^{3}$ (Parise and Guzzi, 1992); it consists of a younger, active part moving within and over an older, inactive part. The active part is $3.9 \mathrm{~km}$ long, with an estimated volume of $20 \times 10^{6} \mathrm{~m}^{3}$ (Parise and Guzzi, 1992).

Dendrochronological data provides a minimum age of 300 years for the younger part, and 700 years for the inactive landslide (Crandell and Varnes, 1960; 1961). Early movement of the landslide dammed the Lake Fork of the Gunnison River and formed Lake San Cristobal. Radiocarbon dates from wood at the base of the landslide deposits indicate that the Slumgullion earth flow probably dammed the Lake

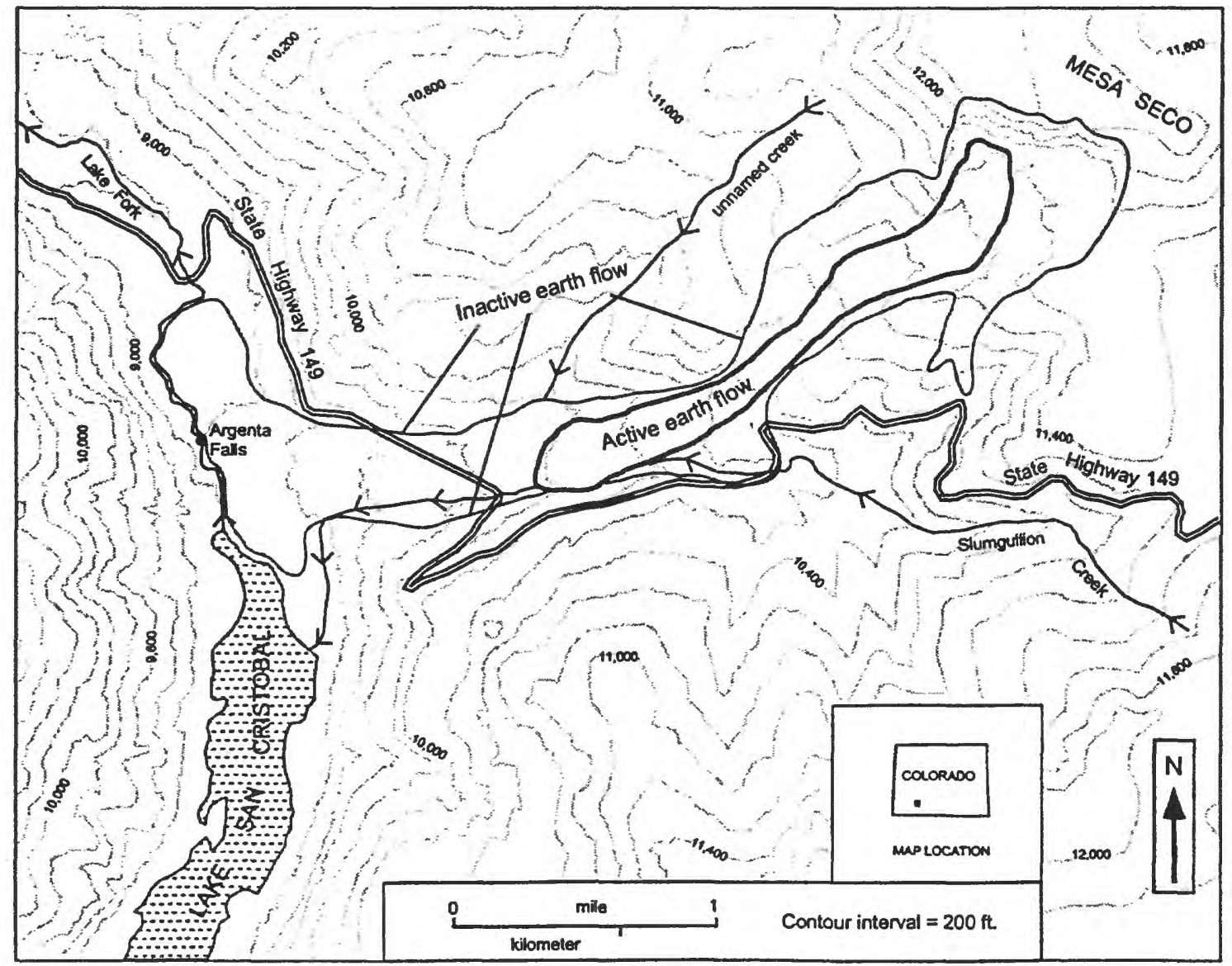

FIGURE 1.Location map showing the boundaries of both inactive and active parts of the Slumgullion earth flow. The active part of the landslide complex is contained within the boundaries of the inactive landslide everywhere except for a small segment on the south side near the toe. 
Table 1 - Morphometry of the inactive Slumgullion earth flow

\begin{tabular}{|c|c|}
\hline Feature & dimension \\
\hline Area of deposit ${ }^{(1)}$ & $4.74 \mathrm{~km}^{2}$ \\
\hline Length & $6.8 \mathrm{~km}$ \\
\hline $\begin{array}{l}\text { Width } \\
\text { - head } \\
\text { - narrowest part } \\
\text { - toe } \\
\end{array}$ & $\begin{array}{c}1,130 \mathrm{~m} \\
290 \mathrm{~m} \\
530 \mathrm{~m} \\
\end{array}$ \\
\hline $\begin{array}{l}\text { Relief } \\
\quad \text { - elevation of top } \\
\text { - elevation of tip }\end{array}$ & $\begin{array}{l}3,700 \mathrm{~m} \\
2,700 \mathrm{~m}\end{array}$ \\
\hline $\begin{array}{l}\text { Average slope } \\
\text { - deposit only } \\
\text { - including main scarp } \\
\end{array}$ & $\begin{array}{l}7(12 \%) \\
8(14 \%) \\
\end{array}$ \\
\hline $\begin{array}{l}\text { Thickness } \\
\text { - average } \\
\text { - average on thalweg of buried valley } \\
\text { - maximum }\end{array}$ & $\begin{array}{c}40 \mathrm{~m} \\
90-100 \mathrm{~m} \\
140 \mathrm{~m} \\
\end{array}$ \\
\hline $\begin{array}{l}\text { Volume } \\
\text { - earth flow deposit } \\
\text { - detached mass }{ }^{(2)}\end{array}$ & $\begin{array}{l}168 \times 10^{6} \mathrm{~m}^{3} \\
142 \times 10^{6} \mathrm{~m}^{3}\end{array}$ \\
\hline Length : width & $>6: 1$ \\
\hline
\end{tabular}

${ }^{1}$ Including the deposit identified by Chleborad (1993).

${ }^{2}$ Including a 30\% bulking factor; for further details see Parise and Guzzi (1992).

Fork between 800 and 900 years B.P. (Madole, 1996).

In the last few years, most studies of the

Slumgullion site have focused on the active portion of the earth flow, and much less attention has been paid to the older and inactive part. Actually, as Varnes and Savage pointed out:

"... stability of the older earth flow is an assumption based on no direct evidence other than verticality of trees on the older slide mass and absence of major distress on Colorado State Highway 149, which crosses it in the upper part" (Varnes and Savage, 1996, p. 4).

Because of the location of State Highway 149 about $250 \mathrm{~m}$ downslope from the active toe and of several resort structures on the southern portion of the inactive landslide blockage, we examined the geologic hazards related to the inactive Slumgullion landslide by field and aerial-photographic methods.

During field work in 1997 we investigated the following active slope movements and erosional processes on the inactive landslide: 1) talus accumulation and rock-fall processes at the head scarp; 2) debris-flow and flooding processes in Slumgullion Creek; 3) areas of surficial erosion; 4) deformation of the inactive earth flow deposit downhill from the active toe; 5) secondary slope movements within the main body of the earth flow. In this report, following a geologic and geomorphologic introduction to the inactive Slumgullion landslide, each of these processes is described, and relative hazards are assessed.

In the present paper we describe the landslide features according to the proposal by the IAEG Commission on Landslides (1990), and follow the system proposed by the UNESCO Working Party on World Landslide Inventory (WP/WLI, 1990; 1993) in the description of landslide activity.

\section{GEOLOGICAL SETTING}

The Slumgullion earth flow is located at the northeastern border of the Lake City caldera (Lipman, 1976), in the San Juan volcanic field of southwestern Colorado. Outcropping rocks in this area of the volcanic district are Tertiary (mostly Oligocene) tuffs and intrusives. Local stratigraphy east of the Lake Fork of the Gunnison River consists of a slightly eastward dipping, buried red-brown tuff (Eureka Member), overlain by a tuffaceous sandstone and by two ash-flow sheets (quartz-latitic and rhyolitic, respectively). The caprock of Mesa Seco (for location, see fig. 1) is rhyolite and andesite lava flows, which are particularly susceptible to acid-sulphate alteration. 
Along the west bank of the Lake Fork, above the buried Eureka member, biotite-quartz latite crops out with good continuity (Lipman, 1976), and the ash-flow sheet exposures are much more limited. There is good exposure of the latite at the Argenta Falls, which is cut in volcanic bedrock a few hundred of meters downhill from the spillway of the lake. Here, the latite is intensely fractured and contains the main discontinuities dipping between $15^{\circ}$ and $25^{\circ}$ toward east and north-east.

The volcanic succession on the west side of Lake Fork is partly covered by Holocene and Pleistocene deposits, mostly glacial and old landslide materials (Lipman, 1976); exposed volcanic rocks comprises perhaps $60 \%$ of the area.

Also in the Slumgullion and the east side of Lake Fork valleys, Pleistocene-age glacial deposits are locally present. Outcrops of glacial deposits are limited to patches of poorly sorted and rounded materials, covered by thick colluvial deposits along the valley sides. Most of the material that crops out along the roadcuts of State Highway 149, on the north-facing valley slope is colluvium derived from the bedrock, as the presence of angular clasts and of poorly sorted deposits, ranging in size from silt to cobble, suggests. Glacial deposits can be distinguished from colluvium by the presence of exotic rock types, including granite, that have been transported into the area.

The boundaries of both active and inactive parts of the Slumgullion earth flow are shown in figure 1. Main dimensions of the entire earth flow complex are listed in table 1.

The main source of the landslide material is a large bowl-shaped reentrant at the southwestern border of Mesa Seco (fig. 1). The main scarp, about $250 \mathrm{~m}$ high, is very steep, in places nearly vertical. Rocks exposed in the scarp include basaltic lava flows of the Miocene Hinsdale Formation, welded ash-flow tuff of the Miocene Sunshine Peak Tuff, and andesitic flows of the Oligocene Uncompahgre Peak volcanics (Lipman, 1976). Moreover, porphyry intrusives and abundant breccias of different origin have recently been identified at the main scarp and mapped (Diehl and Schuster, 1996). A pervasive normal jointing system and vertical fault planes are present throughout the main scarp. These lithological and structural conditions control the main scarp evolution and its retreat (Schuster and Smith, 1996).

The Uncompahgre Peak volcanic units have undergone acid-sulfate alteration, which produced hydrothermal minerals such as alunite, smectite and opal. The hydrothermal brecciation and alteration, combined with the weakening of the rock mass by intersections of numerous faults, is apparently a prime factor in the origin of the Slumgullion landslide (Diehl and Schuster, 1996).

\section{Materials of the Inactive Slumgullion Landslide}

The Slumgullion earth flow deposits are mostly fine sand, silt, and clay which are gray, yellow, light and dark red, brown, chaotic and massive assemblages of poorly sorted fines containing angular rocks ranging from pebbles to boulders. Iron stains on exposed surfaces are common. These materials are evident at the southern and eastern part of the main scarp and along the middle and distal section of the active earth flow; they also form the largest part of the inactive earth flow. In places, within this deposit, large assemblages of stratified volcanic layers showing the original bedding are still recognizable. These layers are typically slightly folded, dismembered, stretched, and distorted yet they maintain the original stratigraphic relationships. Single packages of these rock assemblages are typically 3-10 m long and $2-4 \mathrm{~m}$ thick. A larger portion ( $10 \mathrm{~m}$ in height and 6-15 $\mathrm{m}$ in width) of dismembered, stretched and high-angle dipping stratified rocks was noted on the right side of the active earth flow at about $3,390 \mathrm{~m}$ $(11,120 \mathrm{ft})$ a.s.1.

The variegated deposits show a strong lateral variability. Individual units are typically elongated in the direction of movement resulting in a striped appearance. The lateral variability is accented as well by features such a flank ridge and stream incision that produce longitudinal topographic forms and lateral topographic variability.

Structural features associated with lateral ridges and strike-slip faults are high-angle $\left(65^{\circ}-85^{\circ}\right)$ shear planes, slickensides and grooves; clay-rich silty dykes and extrusions are also present (Baum and Fleming, 1996). Flank-ridge materials are largely derived from hydrothermally altered volcanic rocks (Fleming and others, 1996). The stratified rock assemblages mingled within the massive finegrained materials are less-altered volcanic layers preserved within the altered materials. The slow motion of the stratified rocks downvalley and away from the boundary shear surfaces allows the preservation of the original stratified structure. The largest portion of stratified rocks are interpreted as old block-slide deposits.

The landslide deposit also contains large boulders in the upper part of the active slide and in the southern part of the distal toe damming the Lake San 
Cristobal. They consist of discontinuous accumulations of about $0.1-0.4 \mathrm{~km}^{2}$, and in plan view, the deposits have an elongated lenticular shape with the long axis parallel to the movement direction of the earth flow. The elongated shape of these deposits is the result of deformation within the body of the earth flow. The rock accumulations are stretched by movement-parallel shears, and the clasts are reoriented. The fine-grained matrix covering these deposits is interpreted as a secondary filling related to superficial rain- or snow melt-induced washing out of finer sediment.

The boulder assemblage may be clast- or matrixsupported groups of angular cobbles, boulders, and subordinate blocks. Lichen coatings are widely present on the boulders, especially in the deposit at the distal toe. The fabric is mostly chaotic, but elongated clasts tend to show the long axis perpendicular to the slope direction. They are interpreted as rock fall-derived material collapsed on the earth flow slide during the progressive retreat of the main scarp (the section on rockfall deposits).

\section{GEOMORPHIC SETTING}

In the valley of Slumgullion Creek, as well as at other places in the San Juan Mountains, the topography is generally controlled by the erosional resistance of different types of volcanic rocks. The steep cliffs are composed of lava flows, and unconsolidated and altered tuffs produce gentler topography.

The pre-landslide topography at the valley of Slumgullion Creek was the object of a study by Parise and Guzzi (1992). On the basis of analysis and comparison of shape and morphology of nearby valleys in this sector of the San Juan Mountains to the valley of Slumgullion Creek, Parise and Guzzi (1992) reconstructed the original topography, and computed an average thickness of the displaced material. The average thickness is about $40 \mathrm{~m}$, and the maximum thickness is about $140 \mathrm{~m}$. The maximum thickness occurs where the toe of the active part of the landslide has piled material on top of the inactive part. This point is about $250 \mathrm{~m}$ uphill from where Colorado State Highway 149 crosses the inactive part of the landslide (fig. 1).

Based on the results of seismic reflection and refraction profiles, Williams and Pratt (1996) estimated a maximum thickness of about $95 \mathrm{~m}$ for the landslide, along a profile below the active toe and east of State Highway 149. In the same area, Parise and Guzzi (1992) suggested a thickness of about $120 \mathrm{~m}$. The difference can partly be explained when considering that the pre-landslide topography reconstructed by Parise and Guzzi assumed a V-shape pre-landslide valley, following the shape generally observed in nearby valleys where lithologies similar to those of the valley of Slumgullion Creek crop out. On the other hand, Williams and Pratt (1996) interpreted the pre-landslide valley topography to be Ushaped, so obtaining a lesser value for the thickness of the deposit. The seismic surveys were locally limited, however, by steep topography that prevented acquisition of data across the boundaries of the earth flow and along the stable slopes (Williams and Pratt, 1996). The shape of the valley underlying the landslide deposits could best be resolved by drilling a few boreholes in the area downhill from the active toe.

Main geomorphologic characters of the inactive Slumgullion landslide (fig. 2) are described in the following by means of a longitudinal profile downhill from the active toe. Successively, some considerations about the damming of Lake Fork and the formation of Lake San Cristobal are presented.

\section{Longitudinal Profile of the Inactive Toe}

The longitudinal profile of the inactive Slumgullion earth flow downhill from the active toe (fig. 3, trace of the profile in fig. 2) is mostly hummocky, but the hummocks are smooth and rounded. The profile consists of gentle slopes hundreds of meters across containing closed depressions and ponds. The areas of gentle slopes are joined by intervening steep ramps as much as tens of meters high. The latter are in turn subdivided into several smaller steps.

Four separate zones can be distinguished along the longitudinal profile, from the active to the inactive toe: 1) pond-rich region; 2) main bulge; 3) steps; 4) inactive toe (fig. 3).

The pond-rich region extends from elevation $2,970 \mathrm{~m}$ (tip of the active toe) down to about elevation 2,920 $\mathrm{m}$, for a length of 650 meters (fig. 2). This is mostly an area of gently sloping ground, with several steps up to a few meters high; the highest concentration of ponds occurs here, and there is abundance of water, with both perennial and ephemeral streams flowing off and out of the active landslide.

The development of ponds is usually related to the downhill presence of a bulge within the landslide material. The bulging causes the formation of a gentle uphill-facing slope and consequently, the stagnation of water (Guzzi and Parise, 1992). The pond areas in this portion of the inactive earth flow are typically wet and dark colored. The dark color is locally emphasized by algal growth. The large amount of running water coming from the active earth flow produces in this region a dense but irreg- 


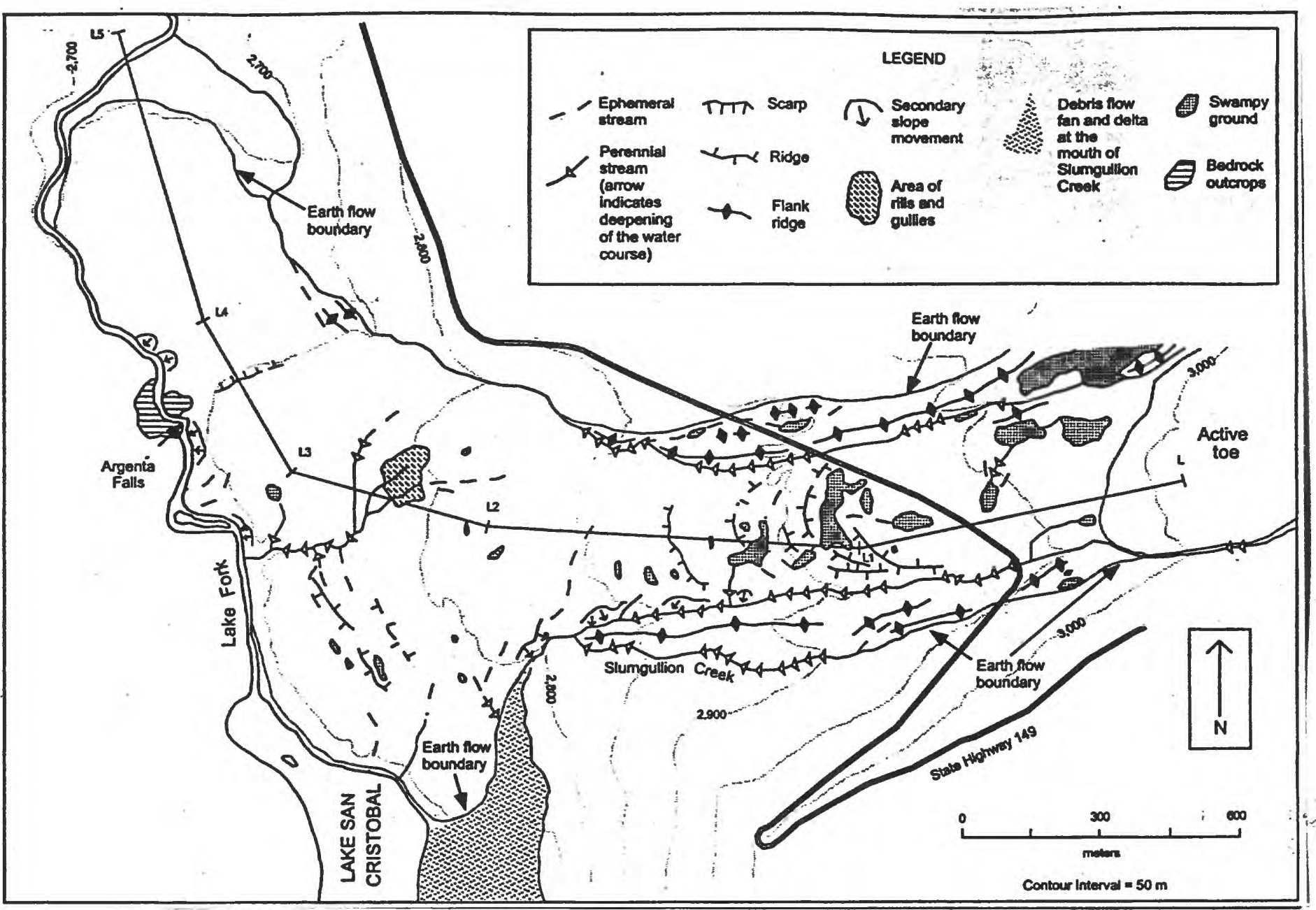

FIGURE 2-Geomorphological sketch of the middle-lower portion of the Slumgullion earth flow, from the active to the inactive toe. Trace of the longitudinal profile (fig. 3 ) is shown.

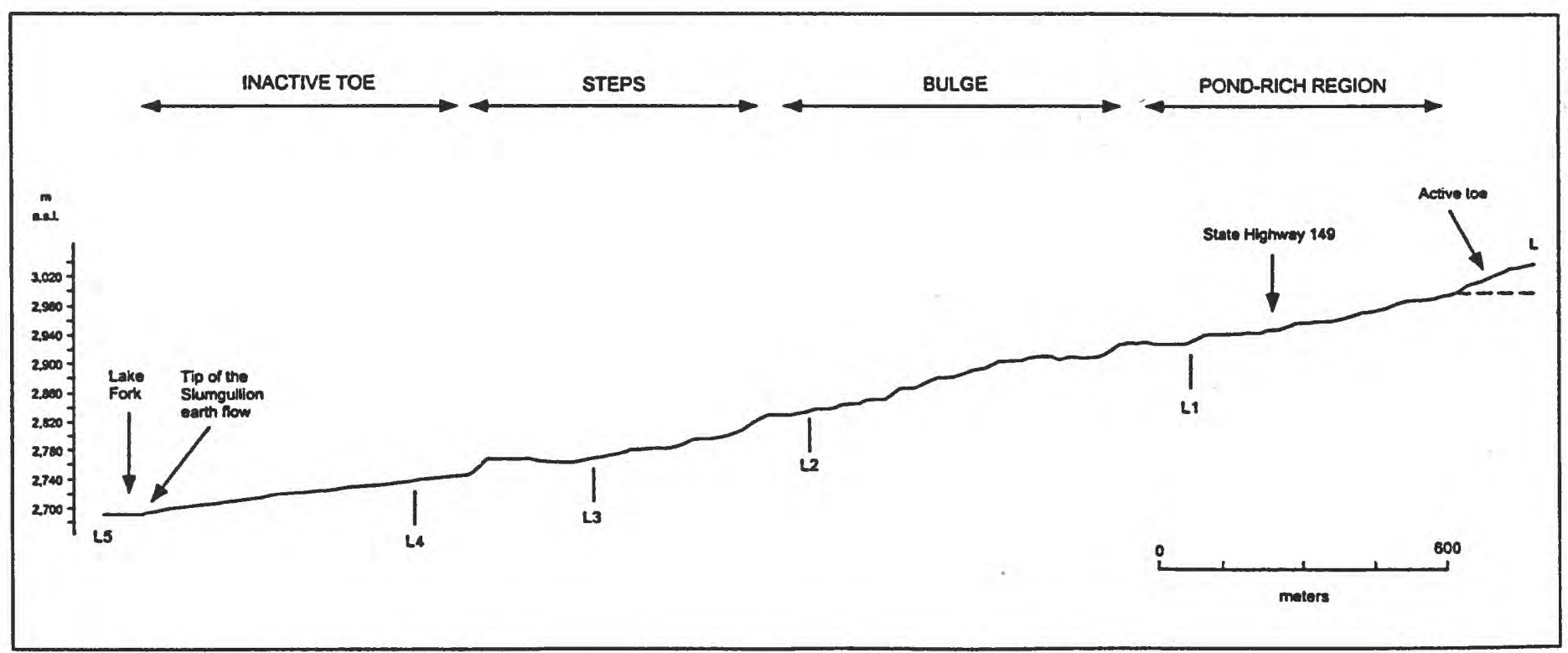

FIGURE 3-Longitudinal profile of the middle-lower part of the inactive Slumgullion earth flow, starting from the toe of the active earth flow. Trace shown in fig. 2. 
ular drainage network. Erosion of the earth-flow deposits and changes in water discharge contribute to frequent diversions in the pattern of the drainage ways.

Farther downslope, the features on the surface of the inactive Slumgullion earth flow are poorly expressed. The combined effects of weathering and erosion processes remodeled most of the surface features produced by the movement, so that the general morphology is rounded and subdued. Only the very large features still preserve some remnants of their original shape.

The main bulge extends between elevation $2,920 \mathrm{~m}$ and elevation $2,820 \mathrm{~m}$, for a length of about $800 \mathrm{~m}$ and contains several internal ridges, mostly convexcurved downslope. Steps up to $17 \mathrm{~m}$ high with slopes that range between $15^{\circ}$ and $25^{\circ}$ join the more gentle hummocky ground. No ponds like the large ones described in the pond-rich region are present, but there are many small closed depressions, commonly with no evidence of inlet or outlet drainage.

As a whole, the main bulge contains some features that are similar but more poorly defined than those observed on the toe of the active part of the Slumgullion earth flow (Guzzi and Parise, 1992; Fleming and others, 1996). The main bulge is also comparable in size to the active toe and perhaps represents an old internal toe in the inactive earth flow, that has been remodeled by erosion and weathering to its present rounded shape.

Still farther downslope, an area of steps extends between elevation $2,820 \mathrm{~m}$ and elevation $2,740 \mathrm{~m}$ and comprises a stretch about $700 \mathrm{~m}$ long of the inactive earth flow. The surface in this area consists of rounded hummocks a few meters high with a few remnants of internal ridges. The ridges are curved downslope, with a slight convex trace such that they resemble waves in the surface of the landslide material.

Two well-defined steps separated by very gently sloping ground are present. The first is between elevation $2,818 \mathrm{~m}$ and $2,784 \mathrm{~m}$, slopes $18^{\circ}$, is about $200 \mathrm{~m}$ long, and connects slopes uphill and downhill that are uniformly $6^{\circ}$. The second step, where the 25-m-high Argenta Falls are located, is between elevation $2,760 \mathrm{~m}$ and $2,738 \mathrm{~m}$. The step slopes $28^{\circ}$ and is one of the steepest slopes within the body of the inactive Slumgullion earth flow. Both steps appear to be breaks in slope of the underlying prelandslide topography. The continuity of the scarps across the earth flow deposit and the lack of convex curvature favor the presence of buried topography in the pre-landslide valley of Slumgullion Creek.

The inactive toe of the earth flow extends between elevation $2,740 \mathrm{~m}$ and elevation $2,710 \mathrm{~m}$, where the tip of the Slumgullion earth flow is located. The slope is uniform at $6^{\circ}$ for the entire length of this distal stretch. The Lake Fork River bounds the toe on its western side and, at the distal end of the landslide, the earth flow turned toward the right, and filled the valley for about $400 \mathrm{~m}$ down Lake Fork valley.

The material in the inactive toe is also different from the rest of the earth flow. Most of the deposit is fine-grained materials derived from the highly altered rocks in the east side of the main scarp, and boulders are rare to absent. This is apparently the

Table 2 - Dimensions of the landslide dam and of Lake San Cristobal

Landslide dam

\begin{tabular}{|l|c|}
\hline \multicolumn{1}{|c|}{ feature } & dimension \\
\hline Length & $2,800 \mathrm{~m}$ \\
\hline Maximum height & $70 \mathrm{~m}$ \\
\hline Maximum width & $570 \mathrm{~m}$ \\
\hline
\end{tabular}

Lake San Cristobal

\begin{tabular}{|l|c|}
\hline \multicolumn{1}{|c|}{ feature } & dimension \\
\hline Length & \\
- original $^{(3)}$ & $4,300 \mathrm{~m}$ \\
- present $^{(3)}$ & $3,300 \mathrm{~m}$ \\
\hline Area & $1.80 \mathrm{~km}^{2}$ \\
${\text { - } \text { original }^{(4)}}_{\text {- present }^{(4)}}$ & $1,33 \mathrm{~km}^{2}$ \\
\hline Maximum depth & $28.5 \mathrm{~m}$ (Crandell \& Varnes, 1961) \\
& $27 \mathrm{~m}$ (Schuster, 1996) \\
\hline Volume & $14 \times 10^{6} \mathrm{~m}^{3}$ \\
\hline
\end{tabular}


In our interpretation, this scarp and the origin of the Argenta Falls are related to an original step in the pre-landslide topography of the valley, connected with a spur of volcanic deposits on its western side. The earth-flow material was deposited over the spur, but did not completely cover it, or did cover it and was partly removed by the river.

\section{THE GEOLOGIC HAZARDS RELATED TO THE INACTIVE SLUMGULLION LANDSLIDE}

\section{Talus Accumulation and Rock-Fall Deposits}

Detailed mapping at the base of the main scarp, together with observation of the deposits, allowed the reconstruction of the evolution of the main scarp and the description of ongoing sedimentary processes. The base of the main scarp is mantled with continuous belt of detrital material consisting of talus cones and rock-fall deposits (fig. 5).

\section{Talus cones}

The talus cones are built by successive and discontinuous accumulation of debris falling from the near-vertical to overhanging rock wall of the main scarp. The cones slope up to $32^{\circ}$ near the apex and grade to about $26^{\circ}$ at the toe. The size and texture of the deposits are strictly related to the rock-type cropping out on the main scarp above the cones, so that it is possible to distinguish those fed by massive, thick-bedded rocks from those fed by thin-bedded, altered rocks. The first type consists of scattered coarse angular boulders, which mainly accumulate at the talus cone toe. They are mostly oriented with the longest axis parallel to the slope. This suggests predominant depositional processes by rolling and bouncing. On the other hand, the upper part of the talus cones is mostly formed of smaller fragments ranging from cobbles to pebbles in size. Boulders typically show collision casts, and dispersed fragments of rocks are generally found between the coarse boulders. In a few sites, boulders broken into small angular fragments like jigsaw puzzles, apparently from freeze-thaw activity, were also observed.

Talus cones fed by thin-bedded, altered rocks consist of coarse to medium angular pebbles and cobbles in a silt-rich, sandy gravel matrix. Elongated clasts are mostly parallel to the slope indicating rolling along the smallest axis or sliding on the sur-

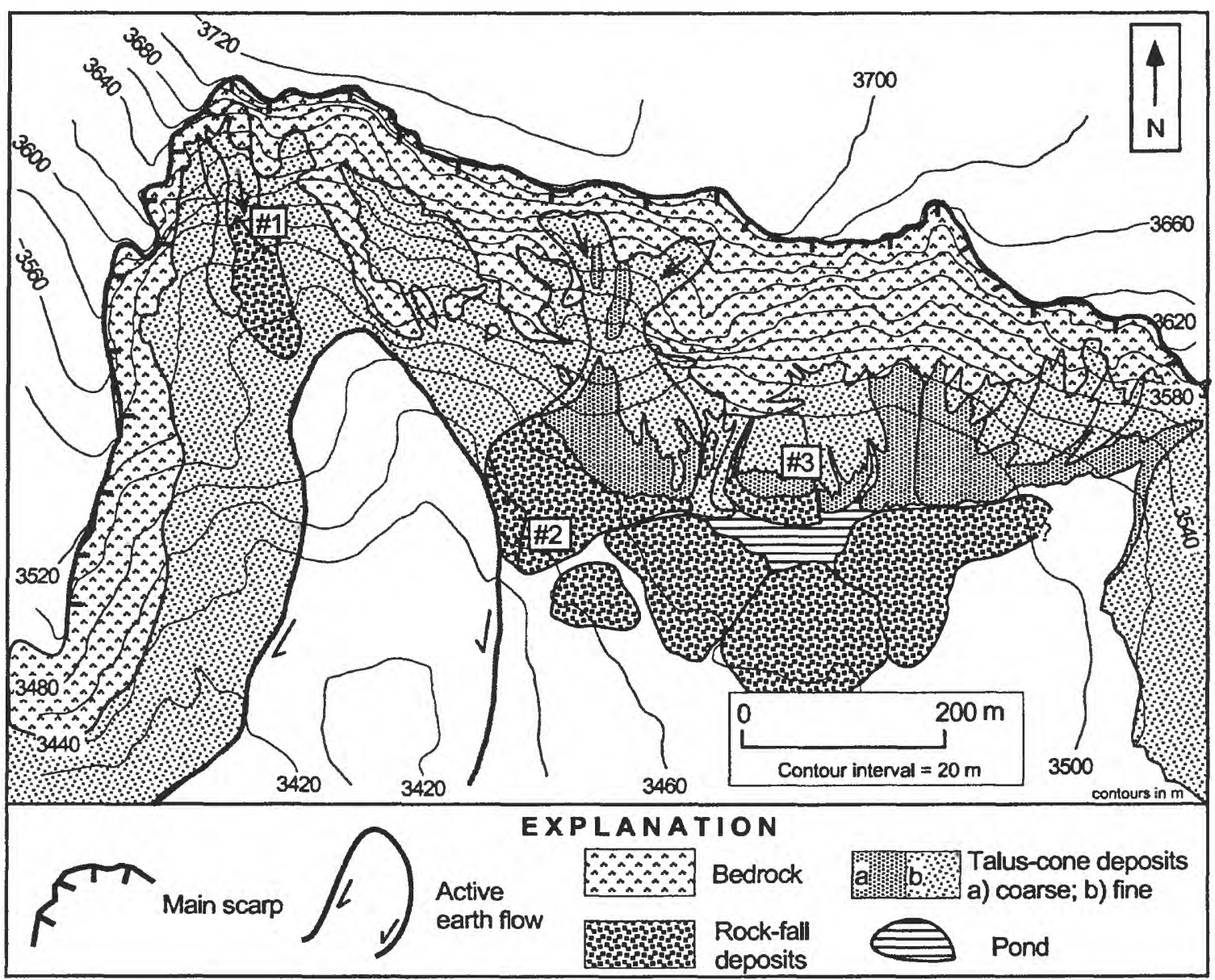

FIGURE 5-

Geologic map of main scarp of the Slumgullion earth flow, showing the talus cones (\#1, $\# 2$, and \#3, as discussed in the text) fed by rock debris coming from the scarp, the rock-fall deposits, and the upper portion of the active earth flow. 
face. The maximum local slope of the talus cones can reach $37^{\circ}$.

Talus cones fed by both type of rocks, as the one labeled as \# 2 in fig. 5, typically have fine-grained sediments in the upper part and boulders and cobbles at the toe. Coarse blocks and boulders at the toe are typically scattered and seldom touch each other. They are partly buried by smaller fragments that have accumulated at the toe by fluvial processes (see fig. 5 in Schuster and Smith, 1996). A few large boulders with the major axes oriented parallel to the slope are found at the apex of the cones and partly immersed within finer sediments.

\section{Rockfall deposits}

Rockfall deposits are widespread at the foot of the Slumgullion main scarp and form a large accumulation of clast-supported angular blocks and coarse boulders, which typically show an irregular hummocky morphology. These deposits can be as much as $10-20 \mathrm{~m}$ thick and tens of meters wide. At present, most of these deposits are covered by thick forest, and the clasts have extensive lichen coatings on their surface.

The best exposed rock-fall deposit is partly buried by talus cone \# 2 (fig. 5). It has a composite longitudinal profile from about $8^{\circ}$ at the top to $41^{\circ}$ at the snout, which is located at the contact with the left boundary of the active part of the Slumgullion earth flow.

The deposit is composed of two different bodies showing different textures and lithologies. The lower part, about $7 \mathrm{~m}$ thick, consists of matrix-supported brecciated boulders associated with finer material ranging from cobbles to fine silt. Small angular coarse sand- to granule-size fragments are abundant; the clasts are mostly composed of highly altered andesite.

The upper part of the deposit is composed of clastsupported angular blocks and large boulders of massive tuffs and basaltic flows. Sediments finer than coarse pebbles are generally not associated with this portion of the deposit. The estimated void ratio of the deposit is a much as 5-15 percent. Typically, the clast fabric is mostly chaotic, the clasts being randomly oriented.

The stratigraphic succession of rock-fall deposit \# 2 is the same as the outcrop in the overhanging main scarp wall. Thus, the deposit is interpreted as the result of two different movement phases that likely occurred as catastrophic rock-fall events. In the first phase, the altered soft rocks outcropping in the middle of the head scarp collapsed and moved downslope mainly by rolling, bouncing and sliding. These processes caused the crushing and comminution of the larger clasts, increasing the amount of fine-grained matrix in the deposit. The first phase induced instability in the overhanging thick-bedded and fractured rocks. The second collapse likely occurred immediately after the first, and large blocks of massive rocks outcropping at the edge of the head scarp failed and accumulated above the previous deposit.

The western part of the main scarp is characterized by slightly altered to unaltered rocks; the eastern and southern parts are mainly made of very altered rocks, almost entirely transformed to clays (Fleming and others, in press). Due to this variation in the composition of the main scarp, rockfalls are more likely to happen in the future at the western part of the main scarp.

Neither rock-fall deposits or talus accumulations directly add a surcharge load to the active Slumgullion landslide. The hazards related to rockfall and talus processes are therefore mostly limited to the base of the head scarp. Nevertheless, there remains a possibility of involvement with currently moving material of the landslide through the occurrence of new rock-fall events from the western portion of the head scarp. A new surcharge on the existing deposits close to the active Slumgullion landslide (\# 1 and \# 2 in fig. 5) could promote further movement in the upper portion of the landslide.

\section{Debris Flows and Flooding}

Debris-flow and flood events occur along Slumgullion Creek near Lake San Cristobal. There is a wide alluvial fan and delta built from successive distribution of debris-flow and flood materials at the mouth of Slumgullion Creek (fig. 4). In this section, we describe geomorphic and sedimentologic characters of both alluvial fan and delta, and then discuss the hazard related to debris-flow and flood processes.

\section{The alluvial fan}

The Slumgullion alluvial fan formed from the Slumgullion Creek at the northeast corner of Lake San Cristobal. The creek follows the southern boundary of the earth flow between the landslide deposits and the bedrock forming the eastern slope of the Lake Fork of the Gunnison River valley. The alluvial-fan surface extends for about $0.49 \mathrm{~km}^{2}$ and has a radial length of about $575 \mathrm{~m}$. The perennial Slumgullion Creek occupies a slightly incised chan- 
nel 2-3 m wide and $0.20-0.50 \mathrm{~m}$ deep in the southern part of the fan.

The fan has a composite slope of between $6.4^{\circ}-2.5^{\circ}$. The fan apex is located at about $2,790 \mathrm{~m}$ a.s.1., the toe at 2,742 $\mathrm{m}$ a.s.1.; here a slope gap indicates the transition between the fan and the delta environment.

Alluvial-fan deposits consist of well-rounded to subrounded boulders, cobbles, coarse to fine pebbles, and granules in a finer matrix that has accumulated by debris-flow processes. The deposits mostly form overlapping lobes 4-7 m long, 2-4 $\mathrm{m}$ wide and 0.2$0.4 \mathrm{~m}$ thick. They are present throughout the fan from the apex to the toe. The maximum clast size is $0.60-0.80 \mathrm{~m}$ in diameter (intermediate axis). In plan view, the elongated clasts forming the lobes are typically imbricated with the intermediate axis parallel to the flow direction. Part of the fan surface is vegetated, pebbles generally are superficially weathered, and lichen coatings are $15-20 \mathrm{~cm}$ in diameter.

Part of the stratigraphy of the fan was exposed in a 1.5-m-deep trench recently dug (May 1997) for a water pipeline. The fan was built by superimposition of several debris-flow events consisting of layers 10$20 \mathrm{~cm}$ thick in $5-8 \mathrm{~m}$-long beds. The material is a clast- to matrix-supported assemblage of cobbles, pebbles, granules in a mud-rich sandy matrix. In cross section, most of the layers display a clast fabric characterized by the long axis generally oriented parallel to the flow and dipping about $10-15^{\circ}$ both up and downstream. These deposits were interpreted as internal lobes accumulated by debris-flow processes.

Also recognized were deposits of clast-supported gravel with imbricated cobbles and pebbles. The intermediate axes of the clasts were generally parallel to the flow. In contrast to the internal lobes, these are interpreted as the frontal lobes of debris flows. Both deposits have planar and slightly undulated, sharp contacts with adjacent layers. In places they are separated by lenticular layers of loose, open cobbles, coarse pebbles, granules, and coarse sand. These lenticular gravels were interpreted as the results of sheetflooding recessional flows (Blair, 1987) following the debris-flow deposition, that remobilized fine-grained sediments from the previously deposited debris flow. Loose gravel can be either formed due to the washing out of the finer sediments from debris-flow lobes or accumulated at the alluvial fan/delta as a consequence of the fluvial activity of the Slumgullion Creek.

Fluvial gravels are often associated with normally graded sequences or horizontally bedded granules and silt-rich, coarse to fine sand. The same deposits were observed along the present channel and interpreted as the result of seasonal flood events (secondary processes, sensu Blair and Mc Pherson, 1994).

Deposits related to the 1987 spring flood (D.J. Varnes, personal commun., 1997) are distributed near the presently incised channel. A 15-m-long, 1.5-3 $\mathrm{m}$ wide and $0.8-1 \mathrm{~m}$ thick levee on the north side of the Slumgullion Creek following the present river course from about $2,810 \mathrm{~m}$ a.s.l. to about $2,800 \mathrm{~m}$ a.s.l. The longitudinal slope is about $5^{\circ}$ whereas the inner and outer slopes range between $35^{\circ}$ and $40^{\circ}$. The material in the levee consist of a chaotic assemblage of small boulders, cobbles, pebbles, granules and silty sand.

Coarser subangular clasts are aligned at the top of the levee. Elongated clasts are mostly oriented parallel to the levee direction. Downslope, the levee grades into lobes reaching the toe. During the 1987 flood event, these deposits extended to the resort facilities located near the channel and $30 \mathrm{~m}$ farther downstream. Here, they have been regraded on both the sides of the river to form artificial levees. Farther downvalley, the debris-flow deposits are dissected by the distributary channels and form small remnants overlapping with the delta sediments.

\section{The delta}

The delta originates at the fan toe. It has a subaerial surface of about $0.6 \mathrm{~km}^{2}$ and a maximum radial length of about $220 \mathrm{~m}$. The surface is planar and has a fairly constant slope of about $0.15^{\circ}$. The delta surface is incised by several distributary channels, 0.5-1.2 $\mathrm{m}$ wide and 0.3-0.8 $\mathrm{m}$ deep, that have originated from Slumgullion Creek. The channels are mostly sinuous displaying small radial curves. At present, the main channel follows the eastern side of the delta.

The distal margin of the delta plain is characterized by a sandy barrier $0.2-0.3 \mathrm{~cm}$ thick and $1-2 \mathrm{~m}$ wide, elongated parallel to the shoreline. The delta front has lenticular and elongated barrier spits oriented parallel to the lake shore. The subaqueous zone is characterized by an increase in the slope up to about $6^{\circ}$.

The low sandy barriers at the shoreline indicate variation in the lake level is mostly related to wave action. Spit deposits were formed by longshore drift mainly related to the increased currents induced by the nearby lake outlet. No internal sedimentary structure has been described for these deposits because of the inacessibility of the site. The topset deposits along the distributary channels at the delta 
surface generally consist of 8-12 cm-thick sequences of fine-grained sediment. Individual layers consist of normally-graded clastics grading upward to clay-rich silt. Here are also beds of massive silty sand ranging from $1-5 \mathrm{~cm}$-thick and coarser layers 3-6 cm thick of medium to fine pebbles. The pebble deposits are observable along the distributary channels where they represent lag deposits. The graded sequences and massive silty sands are fluvial and could result from washing out of debrisflow deposit by the recessional flow following its deposition or simply from sediment transport by Slumgullion Creek across the delta surface. This assemblage is consistent through the observable part of the delta and extends from the transition with the alluvial fan to the shoreline.

Resort facilities located within the depositional area of debris-flow material, as well as along the banks of Slumgullion Creek, leads us to conclude that this area poses one of the most significant hazards related to the earthflow. The occurrence over the years of several debris-flow and flood events highlights the risk related to the presence of human habitation.

\section{Surface Erosion}

Areas of intense surface erosion are scattered over the inactive earth flow, generally corresponding to zones of sparse vegetation, so that running water can easily remove the surface portion of the bare ground and promote the development of rills and gullies.

Distribution of tree cover is essentially continuous on the inactive landslide, except for a few areas of almost bare ground. Such areas, excluding those created by human interaction, are generally sites of springs or of active drainage ways. Water has restricted vegetation either by erosion or ponding. Rills and gullies, with a maximum depth of about 20 $\mathrm{cm}$, mantle sparsely vegetated areas and contribute sediment to Lake San Cristobal and Lake Fork River.

The hazard related to the presence of surface erosional areas at the inactive Slumgullion landslide is limited to a few sites, only the largest of which is shown in fig. 2. Surface erosion processes could increase the amount of sediment transported toward the main water courses during heavy rainstorms and in the snowmelt season; however, because of their location far away from occupied areas, they do not represent a serious hazard.

\section{Ground Deformation Downslope from the Active Toe}

It is interesting to observe the interaction between the active and inactive portions of the Slumgullion landslide in the area downhill from the active toe. To determine if loading exerted by the currently moving material causes deformation of the inactive deposits, a party led by David J. Varnes began surveying this part of the landslide in 1991. The surveys so carried out to date indicate that the inactive part of the Slumgullion earth flow is responding to the load caused by the advancing toe, and is not as stable as previously assumed. The observed deformations are in the range from 20 to $80 \mathrm{~mm}$ (in a 2-year period of observation) near the active toe, and the amount of deformation decreases with distance from the toe (Varnes and others, 1996).

Figure 6 is a sketch of the area downhill from the active toe, showing in detail average values of surveyed points: except for two areas located in the proximity of the active toe, where the ground rose between 25 and $83 \mathrm{~mm}$, the rest of the examined area subsided down to a maximum value of $41 \mathrm{~mm}$ (cf. Varnes and others, 1996).

Deformation of this portion of the inactive Slumgullion landslide is further indicated by its hydrology. The area contains a large amount of surface water flowing off the active portion of the landslide. Drainage in this sector experiences diversions of streams, changes in surficial runoff patterns and changes in boundaries of the main ponds (W.Z.

Savage, personal commun., 1997). From the hydrologic point of view, this area is comparable to most of the surface of the active earth flow, where the surficial drainage pattern changes abruptly in response to active movement of the landslide.

State Highway 149, located near the currently deformed ground, is at long-term risk from the ground deformation downslope from the active toe. Despite the observed ground deformations, observations since 1991 have shown no sign of deformation on the highway. Assuming that the active toe keeps moving at the present rate (maximum value $\approx 2.5$ $\mathrm{m} /$ year), the ground deformation will likely extend in the next 100 years to the area where State Highway 149 runs. Although the evidence is that there will be a diminishing trend in the movement of the active Slumgullion landslide (Parise and Moscariello, 1997; Fleming and others, in press), it is however important to periodically survey the area downslope from the active toe, to detect any possible deformation of the highway. 


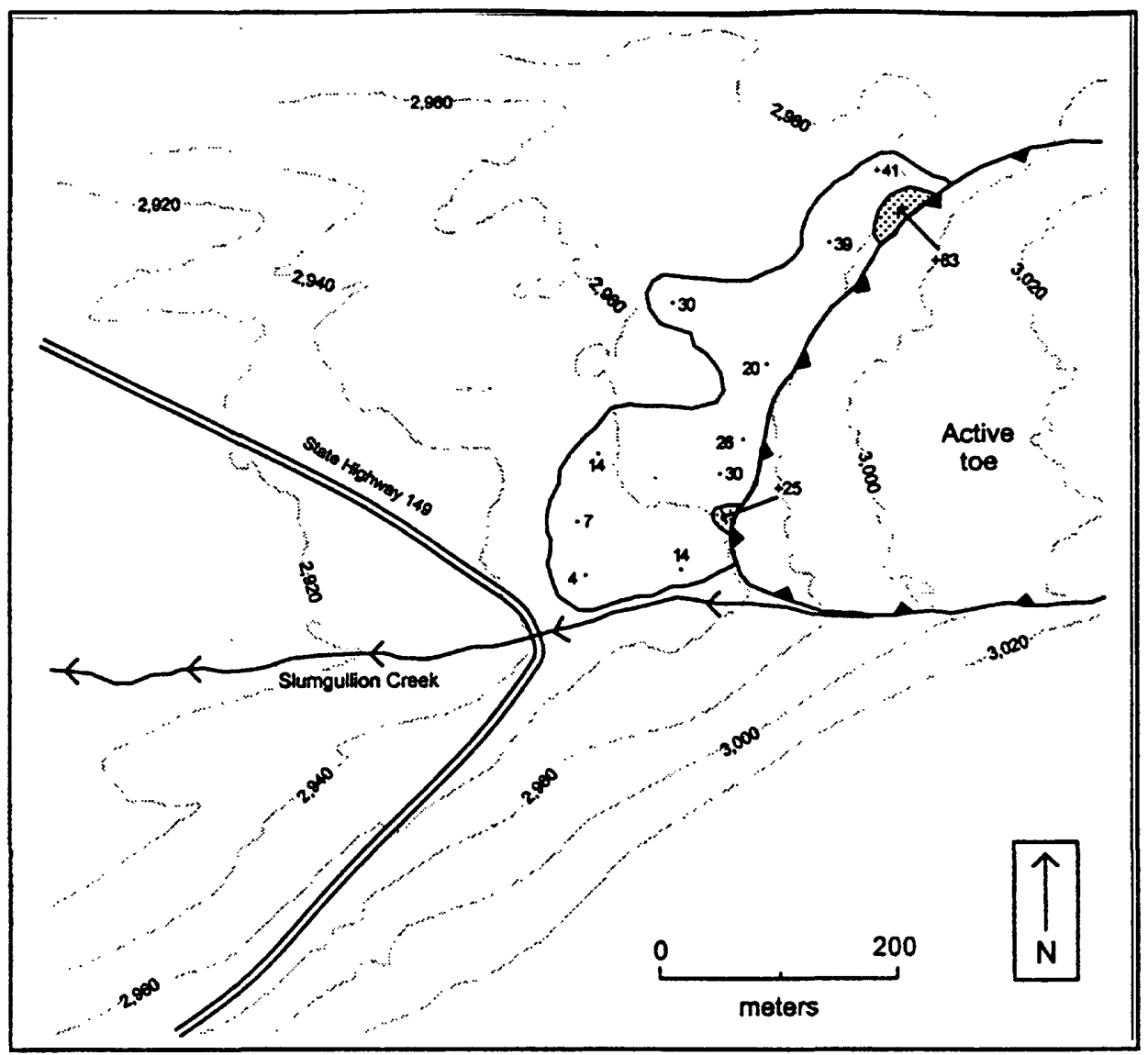

FIGURE 6-Area downhill from the active toe, showing the ground deformation of the inactive landslide deposits for the time period 1991-93 (simplified from Varnes and others, 1996).

Average values of ground deformation (in millimeters) are shown. With the exception of values $+25 \mathrm{~mm}$ and $+83 \mathrm{~mm}$ near the active toe, all other points have negative values, indicating ground subsidence.

\section{Secondary Slope Movements within the Inactive Slumgullion Landslide Deposits} Secondary slope movements, such as shallow landslides, rock falls and debris flows are present on the steeper slopes within the landslide deposits (fig. 2). In particular, the inner and steepest side of the flank ridges are often intensely affected by these movements, especially along Slumgullion Creek and along the unnamed creek bounding the earth flow on the north side. Also the earth flow deposit on the east bank of the Lake Fork shows development of continuous shallow landslides, triggered by river undercutting.

The presence of such secondary slope movements is occasionally shown by tilting or bending of trees located at the edges of main scarps or in the proximity of the landslide boundaries. With the exception of these trees, nearly all trees on the inactive Slumgullion earth flow are vertical and show no sign of disturbance.

Secondary slope movements do not represent a direct hazard to occupied structures. However, they continuously provide material to the main water courses; during debris flows and flooding events, secondary slope movements could significantly increase the amount of sediment transported downvalley, and consequently, the danger for structures located in the proximity of the streams.

\section{Major Collapse of the Main Scarp and Resultant Reactivation of the Slide Deposits}

Perhaps the greatest hazard at the inactive Slumgullion landslide is from a major collapse of a significant part of the headscarp and from remobilization of a large part of the inactive earth flow. According to Madole (1996) and Fleming and others (1996), there have been at least two major main scarp failures in the past 1500 years. There is no evidence for such a collapse other than the historic information that collapses have occurred; however, the combination of steep slopes and highly altered volcanic rocks are always a concern in assessments of long-term stability.

Rock-type is not uniform in the main scarp of the Slumgullion landslide: the western portion is characterized by slightly altered or unaltered rocks, while both eastern and southern parts are mainly very altered rocks, almost entirely transformed to clays. This difference is also visible in the scarp morphology, as shown in three profiles drawn across the main scarp (fig. 7). Profiles A-Al and B-B1, at the western part of the scarp, are subvertical with very steep cliffs. On the other hand, profile $\mathrm{C}-\mathrm{C} 1$, located at the eastern part of the main scarp, is considerably less steep. 


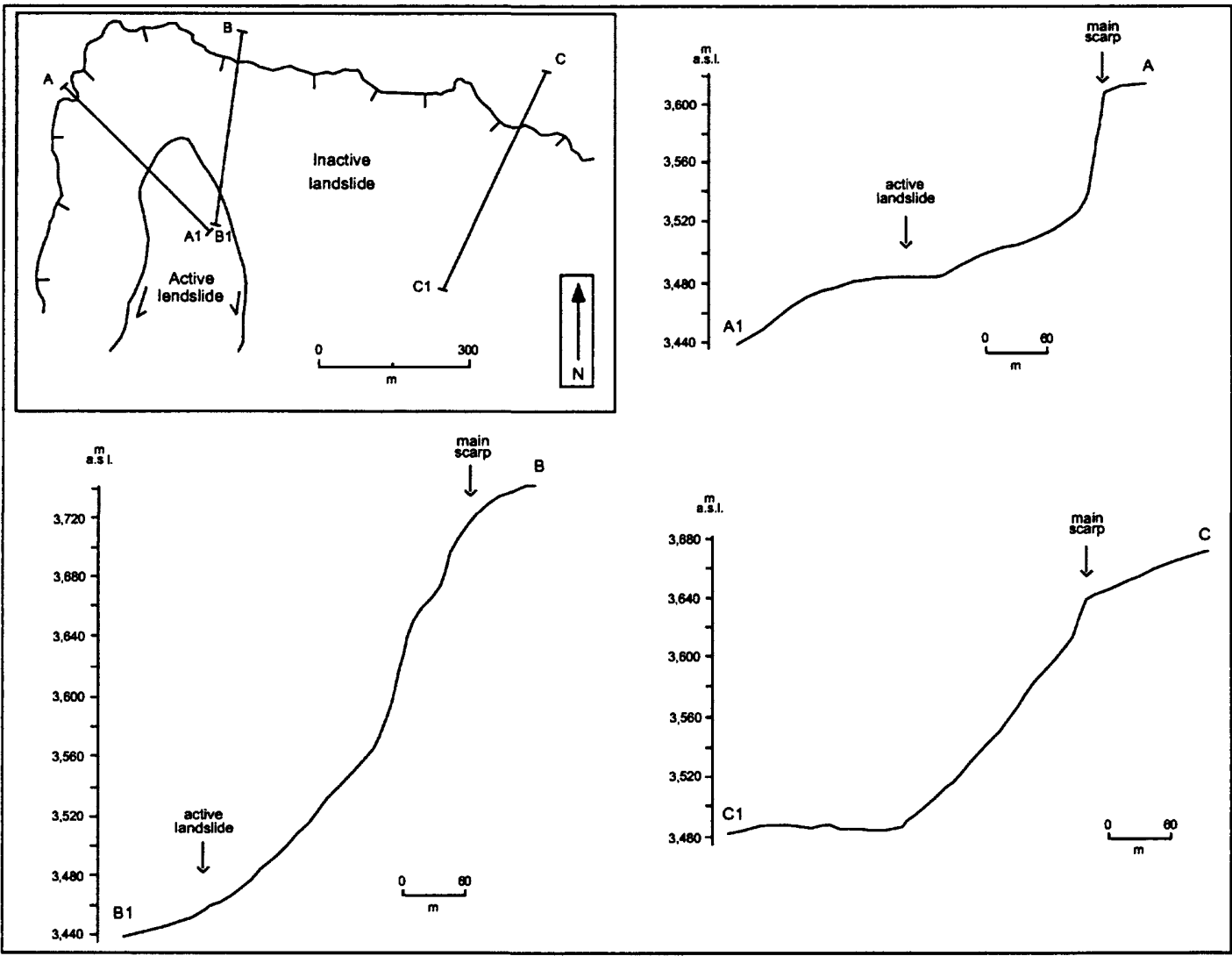

FIGURE 7-Profiles at the main scarp of the inactive Slumgullion landslide. Inset map shows location.

As described in the section on rock-fall deposits; the possibility of future collapse seems more likely to happen in the western sector of the main scarp. A few cracks and other deformation features are recognizable uphill from the main scarp in its western portion. Such features are mostly limited to a narrow 20-m-wide band which follows the main scarp boundary. Evidence for a future collapse is limited to these deformation features. Observations at the base of the main scarp between 1989 and 1992 show that only a few small rockfalls occurred during this period (Schuster and Smith, 1996). Activity of the main scarp appears to be limited to sporadic and small-sized falls, and we speculate that a new catastrophic event, although not to be excluded in the long run, is not likely to happen in the short term.

However, considering the possibility of a future collapse in the western part of the main scarp, this could involve a volume of material in the order of a few hundred of thousands of cubic meters. Due to unaltered or poorly altered rocks cropping out in this sector of the scarp, the collapse would likely happen as a single event; furthermore, because of the proximity of the head of the active Slumgullion landslide to the probable source area of the collapse, the latter could promote further movement to the currently moving material, and remobilization of part of the inactive landslide deposits downslope from the toe of the active Slumgullion landslide.

\section{CONCLUSIONS}

Several geologic hazards related to the inactive Slumgullion landslide exist. Besides the long-term possibility of a major collapse of the main scarp, other principal concerns include rock-fall and talus accumulation processes at the head scarp, areas of surficial erosion, debris-flow and flood processes in Slumgullion Creek, deformation of the inactive earth flow deposit downhill from the active toe, and secondary slope movements within the main body of the earth flow. In particular, because of the presence of several resort facilities very close to the

Slumgullion Creek and within the boundaries of the depositional area of debris-flow materials, the alluvial fan at the mouth of the creek seems to be one of the areas most exposed to geologic hazards posed by the Slumgullion earth flow. Another hazard is represented by ground deformations in the inactive deposits downslope from the active toe, particularly State Highway 149; it is advisable to keep monitoring this sector of the landslide to detect possible extension of the deformation to the highway.

\section{ACKNOWLEDGMENTS}

This research is part of the post-doctoral activity of A. Moscariello granted by the Swiss National Science Foundation. This research has also been partly sponsored by the Académie Suisse de Sciences Naturelles and Fond Édouard Claparède, Geneva. 
David J. Varnes shared with us in the course of many discussions the thorough knowledge he has of the Slumgullion landslide; furthermore, he provided us with published and unpublished material regarding the landslide. Robert W. Fleming patiently accompanied the course of our work with always precious advice. Rex L. Baum gave useful comments on a preliminary version of the report. To these people, we express our sincere gratitude.

\section{REFERENCES}

Atwood, W.W. and Mather, K.F., 1932, Physiography and Quaternary geology of the San Juan Mountains, Colorado: U.S. Geological Survey Professional Paper 166, 176 p.

Baum, R.L., and Fleming, R.W., 1996, Kinematic studies of the Slumgullion landslide, Hinsdale County, Colorado, in Varnes, D.J. and Savage, W.Z. (eds.), The Slumgullion earth flow-a largescale natural laboratory: U.S. Geological Survey Bulletin 2130, p. 9-12.

Blair, C., 1987, Sedimentary processes, vertical stratification sequences, and geomorphology of the Roaring River alluvial fan, Rocky Mountain National Park, Colorado: J. Sediment. Petrol., 57, p. 1-18.

Blair, T.C., and Mc Pherson, J.G., 1994, Alluvial fan processes and forms, in Abrahams, A.D. and Parsons, A.J. (eds.), Geomorphology of desert environments: London, Chapman and Hall, p. 354-402.

Burbank, W.S., 1947, Lake City area, Hinsdale County: Mineral Resources of Colorado, Colorado Mineral Resources Board, p. 439-443.

Chleborad, A.F., 1993, Description, origin, and implications of a new identified Slumgullion landslide deposit, San Juan Mountains, southwestern Colorado: U.S. Geological Survey Open-File Report 93-548, 17 p.

Crandell, D.R., and Varnes, D.J., 1960, Slumgullion earthflow and earthslide near Lake City, Colorado [abs.]: Geological Society of America Bulletin, v. 71 , no. 12 , pt. 2 , p. 1846 .

Crandell, D.R., and Varnes D.J., 1961, Movement of the Slumgullion earthflow near Lake City, Colorado, in Short papers in the geologic and hydrologic sciences: U.S. Geological Survey Professional Paper 424-B, p. B136-B139.

Cross W., 1909, The Slumgullion mud flow: Science, v. 30, no. 760 , p. 126-127.
Diehl, S.F., and Schuster, R.L., 1996, Preliminary geologic map and alteration mineralogy of the main scarp of the Slumgullion landslide, in Varnes, D.J. and Savage, W.Z. (eds.), The Slumgullion earth flow-a large-scale natural laboratory: U.S. Geological Survey Bulletin 2130, p. 13-19.

Endlich, F.M., 1876, Report of F.M. Endlich: U.S. Geological and Geographical Survey (Hayden) of the Territories, Annual Report 1874, 203 p.

Fleming, R.W., Baum, R.L., and Savage, W.Z., 1996, The Slumgullion landslide, Hinsdale County, Colorado: Guidebook for field trips, Geological Society of America Annual Meeting, Denver, Colo., October 1996 (Available in CD-Rom from the Colorado Geological Survey), 21 p.

Fleming, R.W., Baum, R.L., and Giardino, M., in press, Map and description of the active part of the Slumgullion landslide, Hinsdale County, Colorado: U.S. Geological Survey Miscellaneous Series Map, scale 1:1,000.

Guzzi, R., and Parise, M., 1992, Surface features and kinematics of the Slumgullion landslide, near Lake City, Colorado: U.S. Geological Survey Open-File Report 92-252, 45 p.

Howe, E., 1909, Landslides in the San Juan Mountains, Colorado: U.S. Geological Survey Professional Paper 67, 58 p.

IAEG Commission on Landslides, 1990, Suggested nomenclature for landslides: Bulletin of the International Association of Engineering Geology, 41 , p. 13-16.

Lipman, P.W., 1976, Geologic map of the Lake City caldera area, western San Juan Mountains, southwestern Colorado: U.S. Geological Survey Miscellaneous Investigations Series Map I-962, scale $1: 48,000$.

Madole, R., 1996, Preliminary chronology of the Slumgullion landslide, Hinsdale County, Colorado, in Varnes, D.J. and Savage, W.Z. (eds.), The Slumgullion earth flow-a large-scale natural laboratory: U.S. Geological Survey Bulletin 2130, p. 5-7.

Parise, M., and Guzzi, R., 1992, Volume and shape of the active and inactive parts of the Slumgullion landslide, Hinsdale County, Colorado: U.S. Geological Survey Open-File Report 92-216, 29 p.

Savage, W.Z., and Fleming, R.W., 1996, Slumgullion landslide fault creep studies, in Varnes, D.J. and Savage, W.Z. (eds.), The Slumgullion earth flow-a large-scale natural laboratory: U.S. Geological Survey Bulletin 2130, p. 73-76. 
Schuster, R.L., 1985, Landslide dams in the Western United States: Proceedings of the IVth International Conference and Field Workshop on Landslides, Tokyo, p. 411-418.

Schuster, R.L., 1996, Slumgullion landslide dam and its effects on the Lake Fork, in Varnes, D.J. and Savage, W.Z. (eds.), The Slumgullion earth flow-a large-scale natural laboratory: U.S. Geological Survey Bulletin 2130, p. 35-41.

Schuster, R.L., and Smith, W.K., 1996, Retreat of the Slumgullion main scarp, in Varnes, D.J. and Savage, W.Z. (eds.), The Slumgullion earth flowa large-scale natural laboratory: U.S. Geological Survey Bulletin 2130, p. 21-28.

Varnes, D.J., and Savage, W.Z., 1996, Introduction, in Varnes, D.J. and Savage, W.Z. (eds.), The Slumgullion earth flow-a large-scale natural laboratory: U.S. Geological Survey Bulletin 2130 , p. 1-4.

Varnes, D.J., Smith, W.K., Savage, W.Z., and Powers, P.S., 1996, Deformation and control surveys, Slumgullion landslide, in Varnes, D.J. and Savage, W.Z. (eds.), The Slumgullion earth flowa large-scale natural laboratory: U.S. Geological Survey Bulletin 2130, p. 43-49.
Williams, R.A., and Pratt, T.L., 1996, Detection of the base of Slumgullion landslide, Colorado, by seismic reflection and refraction methods, in Varnes, D.J. and Savage, W.Z. (eds.), The Slumgullion earth flow-a large-scale natural laboratory: U.S. Geological Survey Bulletin 2130, p. 77-83.

WP/WLI (Working Party on World Landslide Inventory), 1990, A suggested method for reporting a landslide: Bulletin of the International Association of Engineering Geology, 41, p. 5-12.

WP/WLI (Working Party on World Landslide Inventory), 1993, A suggested method for describing the activity of a landslide: Bulletin of the International Association of Engineering Geology, 47 , p. 53-57. 